\title{
Concurso de Pósters
}

\author{
Resúmenes de Trabajos
}

Coordinadores: María del Pilar Bernal, Comité Académico ALOP.

\author{
CAMPOS C, NARANJO C, CASTILLO I.
}

\section{EVOLUCIÓN ÍNDICE CEOD/COPD EN NIÑOS ATENDIDOS EN ESTABLECIMIENTOS DE ATENCIÓN PRIMARIA - SSMS PERÍODO 2009-2014}

Introducción: El Servicio de Salud Metropolitano Sur tiene a su cargo la supervisión de los Centros de Atención Primaria de área sur de Santiago, encargados de acciones de promoción, prevención y tratamiento odontológico de la población beneficiaria del sistema público se salud. Se hace necesario analizar el estado de salud bucal a lo largo del tiempo de los niños que reciben atención dental en estos establecimientos para evaluar el impacto de dichas intervenciones. Objetivos: Determinar la evolución del índice ceod/COPD a través del tiempo en niños de 2, 4, 6 y 12 años atendidos en establecimientos de salud dependientes del SSMS. Métodos: Estudio descriptivo de corte transversal. Durante los meses de junio a noviembre del año 2015 se analizaron datos provenientes del registro estadístico mensual (REM) Hoja A09, de los establecimientos públicos de atención primaria bajo el área de influencia del SSMS. Estudio aprobado por el Comité de Ética del Servicio de Salud Metropolitano Sur. Resultados: Los datos obtenidos fueron tabulados en planilla Excel. Se calcularon promedios, porcentajes y sumatoria. Durante el periodo analizado, se registró un $\mathrm{N}=193.715$ de ingresos a tratamiento odontológico para las edades antes mencionadas. El porcentaje de niños sin historial de caries aumentó en el SSMS durante el periodo 2009-2014 en todos los grupos estudiados siendo el aumento más significativo en los grupos de 6 y 12 años (10 puntos porcentuales) v/s los grupos de 2 y 4 años (4 puntos porcentuales). Se observó una disminución del número de niños con COPD mayor a 4, siendo esta disminución más significativo en el grupo de 12 años (13 puntos porcentuales). Conclusión: Alta prevalencia de caries en el periodo evaluado, sin embargo, el porcentaje de niños sin historial de caries aumentó en el SSMS durante el periodo 2009-2014, además de disminuir los niños con un ceod/COPD $>4$.

\section{EVOLUTION CEOD / COPD IN CHILDREN TREATED IN PRIMARY CARE - SSMS PERIOD 2009-2014}

Introduction: South Metropolitan Health Service is responsible for the supervision of primary care centers south of Santiago area, responsible for promotion, prevention and dental treatment of the beneficiaries of the public health system. It is necessary to analyze the state 
of oral health over time children receiving dental care at these facilities to assess the impact of such interventions. Aim: To determine the evolution of ceo / COPD over time in children aged 2, 4, 6 and 12 years treated at health facilities dependent SSMS. Methods: Cross-sectional study. During the months of June to November 2015 data from the monthly statistical record (REM) Sheet A09 of public primary care facilities under the area of influence of SSMS were analyzed. Study approved by the Ethics Committee of the South Metropolitan Health Service. Results: The obtained data were tabulated in an Excel spreadsheet. Averages and percentages were calculated. During the period under review, an $\mathrm{N}=193,715$ revenue dental treatment for the above age was recorded. The percentage of children with no history of caries increased in SSMS during the period 2009-2014 in all groups studied being the most significant groups of 6 and 12 years (10 percentage points) $\mathrm{v} / \mathrm{s}$ increase the groups 2 and 4 years (4 percentage points). A decrease in the number of children with COPD $>4$ was observed, this being more significant in the group of 12 years (13 percentage points) decrease. Conclusion: High prevalence of caries in the evaluated period, however, the percentage of children with no history of caries increased in SSMS during the period 2009-2014, in addition to reducing children with ceod / COPD $>4$.

\section{CAMPOS C, NARANJO C, CASTILLO I.}

\section{APLICACIÓN DE BARNIZ FLUORADO EN NIÑOS ATENDIDOS EN ESTABLECIMIENTOS DE ATENCIÓN PRIMARIA SSMS PERÍODO 2009-2014}

Introducción: El Servicio de Salud Metropolitano Sur tiene a su cargo la supervisión de los Centros de Atención Primaria de área sur de Santiago, encargados de acciones de promoción, prevención y tratamiento odontológico de la población beneficiaria del sistema público se salud. La aplicación de fluor forma parte de la canasta de prestaciones en este nivel de atención, por lo que, atendiendo a su nivel de costo efectividad, se hace necesario evaluar el grado de utilización de éste en niños que reciben tratamiento odontológico. Objetivos: Determinar promedio de aplicaciones de flúor realizadas en niños de 2, 4, 6 y 12 años atendidos en el SSMS, entre los años 2009-2014. Métodos: Estudio descriptivo de corte transversal. Durante los meses de junio a noviembre del año 2015 se analizaron datos provenientes del registro estadístico mensual (REM) Hoja A09, de establecimientos públicos de atención primaria bajo el área de influencia del SSMS. Estudio aprobado por Comité de Ética Servicio de Salud Metropolitano Sur. Resultados: Los datos obtenidos fueron tabulados en planilla Excel. Se calcularon promedios, porcentajes y sumatoria. Durante el periodo analizado, se registró un $\mathrm{N}=193.715$ de ingresos a tratamiento odontológico para las edades antes mencionadas. Se observó un aumento en el número de fluoraciones realizadas por niño ingresado a tratamiento en el periodo 2009 - 2014. Durante el año 2014 se registraron 0,09 aplicaciones por niño de 2 años, 0,18 a los 4 años, 0,2 a los 6 años y 0,15 por cada niño de 12 años ingresado a tratamiento odontológico. Conclusión: A pesar del aumento en la utilización de esta medida, aun se observa una muy baja utilización de flúor como medida preventiva. Esto pudiera deberse a falta de actualización de los odontólogos tratantes o a la falta de acceso a flúor barniz dentro del arsenal farmacológico disponible en atención primaria. 


\section{FLUORIDE VARNISH APPLICATION IN CHILDREN TREATED IN PRIMARY CARE SSMS PERIOD 2009-2014}

Introduction: South Metropolitan Health Service is responsible for the supervision of primary care centers south of Santiago area, responsible for promotion, prevention and dental treatment of the beneficiaries of the public health system. The fluoride application is part of the benefits in this level of care, because of its level of cost effectiveness, it is necessary to assess the degree of use of it in children receiving dental treatment. Aim: To determine average fluoride applications in children aged 2, 4, 6 and 12 years served in the SSMS, between years 2009-2014. Methods: Cross-sectional study. During the months of June to November 2015 data from the monthly statistical record (REM) Sheet A09 of public primary care facilities under the area of influence of SSMS were analyzed. Study approved by the Ethics Committee of the South Metropolitan Health Service. Results: The obtained data were tabulated in an Excel spreadsheet. Averages and percentages were calculated. During the period under review, an $\mathrm{N}=193,715$ revenue dental treatment for the above age was recorded. An increase in the number of fluoride aplications made by child admitted to treatment in the period 2009 - 2014 was observed. During 2014 applications were registered 0.09 per child 2 years, 0.18 at 4 years, 0.2 to 6 years and 0.15 per child under 12 years admitted to dental treatment. Conclusion: Despite the increase in the use of this measure, even a very low use of fluoride as a preventive measure is observed. This could be due to lack of updating of dentists or lack of access to fluoride varnish in the arsenal of drugs available in primary care.

MONDELOAM, GALARZA R, GONZALEZ N.

\section{VALORACIÓN DE TRATAMIENTOS DE TRASTORNOS TÉMPOROMANDIBULARES (TTM) EN NIÑO}

Objetivos: Valorar tipo de abordaje terapéutico, evolución y adhesión al tratamiento de pacientes pediátricos con TTM. Métodos: 100 niños de 13,2 + 1,3 años diagnosticados con el $\mathrm{CDI} / \mathrm{TTM}$ por docentes estandarizados (Kappa=0.88), fueron asistidos por el equipo multidisciplinario de la Cátedra entre 2012 y 2015. Se dividieron en 3 grupos: dolor muscular (Ia), dolor con limitación de apertura (Ib) y desplazamiento de disco con reducción (IIa). Se utilizaron promedios, desvío standard, porcentajes con IC 95\% y comparaciones mediante test exacto de Fisher. Resultados: Ia quedó conformado por 58 niños, Ib por 32 y IIa por 8 (2conIIb y IIc fueron excluidos). Luego de indicaciones sintomáticas adhirieron al tratamiento: Ia $37,9 \%$, Ib 46,9\%, IIa 62,5\% (p=0,36). Recibieron intermediarios oclusales (IO) el 38,1 \% $(23,4-52,8)$. Se indicó reeducación kinesiológica al 38,1 \% (23,4-52,8), fonoaudiológica al 52,4 $\%(37,3-67,5)$ y orientación psicológica al 12,2 \% (2,2-22,2). Los tratamientos se dividieron en cuatro grupos: únicamente con $\mathrm{IO}(\mathrm{A})$, tratamientos alternativos a los $\mathrm{IO}(\mathrm{B})$, tratados con $\mathrm{IO}$ y alternativos (C) y solo tratamiento sintomático (D). Fueron asignados al grupo A el 9,5\%; $13,3 \%$ y $20 \%$, al grupo B el $42,9 \% ; 33,3 \%$ y $60 \%$, al C el 23,8 \%; 33,3 \% y 0\%, y al D el 23,8 \%; $20 \%$ y $20 \%$ para Ia, Ib y IIa respectivamente $(\mathrm{p}=0,83)$. La duración del tratamiento en meses fue: Ia 3,8 $\pm 3,1$, Ib 3,5 $\pm 2,4$ y IIa 3,2 $\pm 2,17$. La evolución mostró una mejoría del 100\%, 93,3\% 
y $100 \%$ para Ia, Ib y IIa respectivamente $(\mathrm{p}=0,48)$. El tiempo de controles fue $17 \pm 5$ meses. Conclusiones: En esta muestra solo en los pacientes que presentaron síntomas severos se observó alta adhesión al tratamiento. El abordaje multidisciplinario mostró ser efectivo para la resolución, sin uso sistemático de intermediarios oclusales.

\section{TMD IN CHILDREN: APPRAISEMENT OF TREATMENTS}

Objectives: Appraise different approaches, evolution and compliance to treatment in patients diagnosed through TMD. Method: 100 children 13,2 + 1,32 years diagnosed by calibrated examiners in RDC/TMD (Kappa $=0.88$ ), they were assisted at the Department of Dentistry for Children during 2012 and 2015 by a multidisciplinary team. They were divided in 3 groups according to the diagnosis: muscle pain (Ia), pain and opening limitation $(\mathrm{Ib})$ and disk displacement with reduction (IIa). Averages, standard desviation, percentages with IC 95\% were used and comparisons with Fisher exact test. Results: la was formed of 58 children, $\mathrm{lb}$ of 32 and lla of 8 ( 2 with $1 \mathrm{lb}$ and llc were excluded ). After symptomatic indications adhered to treatment: $37,9 \% \mathrm{la}, 46,9 \% \mathrm{lb}, 62,5 \%$ lla $(\mathrm{p}=0,36)$. They received occlusal splints (IO) $38,1 \%(23,4-52,8)$. Kinesiology rehabilitation indicated at $38,1 \%(23,4-52,8)$, phonoaudiological in $52.4 \%(37,3-67,5)$ and psychotherapy in $12,2 \%(2,2-22,2)$. The treatments were divided into four groups: only $\mathrm{IO}(\mathrm{A})$, alternative treatments to $\mathrm{IO}(\mathrm{B})$, treated with $\mathrm{IO}$ and alternative $(C)$ and only symptomatic treatment $(D)$.They were assigned to group A 9,5\%; $13,3 \%$ and $20 \%$, group B $42,9 \% ; 33,3 \%$ and $60 \%, C$ at $23,8 \% ; 33,0 \%$ and $0 \%$ and $\mathrm{D} 23,8 \% ; 20 \%$ and $20 \%$ for $\mathrm{la}, \mathrm{lb}$ and lla respectively ( $\mathrm{p}=0,83$ ). Duration treatment was: ( Ia ) 3,8 $\pm 3,1, \mathrm{l} \mathrm{lb}$ ) 3,5 $\pm 2,4$ and ( IIa) 3,2 $\pm 2,7$ months. The evolution showed an improvement of $100 \%, 93,3$ and $100 \%$ for $\mathrm{la}, \mathrm{lb}$ and lla respectively $(\mathrm{p}=0,48)$. The control time was $17 \pm 5$ months. Conclusions: In this sample most of the patients showed non-adherence to treatment, with the exception of those who revealed severe symptoms. The current study shows the effectiveness of the multidisciplinary approach without systematic splint therapy

VINAGRE M, TAPIA R, NARANJO C, FLORES V, DEL REALA.

\section{OCLUSIÓN TUBULAR COMO TRATAMIENTO DE HIPER- SENSIBILIDAD CAUSADA POR LA HIPOMINERALIZACIÓN MOLAR INCISAL: REVISIÓN NARRATIVA.}

Introducción: La Hipomineralización Molar Incisal (MIH) presenta una prevalencia entre 11,4 y $40,2 \%$ en Latinoamérica. Una de sus consecuencias clínicas es la hipersensibilidad. En la literatura se reporta la oclusión tubular como tratamiento, dado que impide el movimiento del flujo intratubular evitando así el dolor. Objetivo general: Describir según la literatura el tratamiento de la hipersensibilidad causada por la MIH mediante oclusión tubular. Método: Se realizó una búsqueda en inglés y español, entre los años 2001 y 2015. Resultados: Se seleccionaron 35 artículos. Proponen como tratamiento de la hipersensibilidad 
producida por MIH la oclusión tubular mediante remineralización o terapia restauradora. Discusión: Estudios demuestran que el tratamiento más eficaz es una combinación de agentes remineralizadores: flúor, ozono o proteína $\mathrm{CPP}-\mathrm{ACP}$, o bien, la ejecución de una terapia restauradora: resina compuesta, vidrio ionómero o coronas preformadas. Conclusión: Para el tratamiento de la hipersensibilidad en dientes con MIH son efectivos la combinación de agentes remineralizadores y/o terapia restauradora.

\section{TUBULAR OCCLUSION AS A TREATMENT OF HYPERSENSITI- VITY CAUSED BY MOLAR INCISOR HYPOMINERALIZATION: NARRATIVE REVIEW.}

Introduction: Molar Incisor Hypomineralisation (MIH) has a prevalence between 11, 4 and 40, 2\% in Latin America. One of the clinical consequences is hypersensitivity. Literature reports tubular occlusion as a proper treatment, because it avoids the movement of intratubular fluid and with it pain. General Objective: Describe according to literature the treatment of hypersensitivity caused by MIH through tubular occlusion. Method: A search was conducted in English and Spanish, between 2001 and 2015. Results: 35 articles were selected and propose tubular occlusion as treatment for hypersensitivity caused by MIH through remineralization or restorative materials. Discussion: Studies have shown that the most effective treatment is a combination of remineralizing agents: fluoride, ozone and CPP-ACP protein, or the indication of composite restoration, glass ionomer or preformed crowns. Conclusions: For the treatment of hypersensitivity on MIH, the combination of remineralizing agents and/or restorative therapy have shown to be effective.

ZAMORA A, CASTILLO C.

\section{TRASTORNOS RESPIRATORIOS DEL SUEÑO COMO FACTOR DE RIESGO EN BRUXISMO DEL SUEÑO EN PREESCOLARES.}

Introducción: En la actualidad son frecuentes las consultas por bruxismo de los padres de niños preescolares. La tendencia de los odontólogos es considerarlo como un acto fisiológi$\mathrm{co}$, omitiendo posibles factores que puedan estar alterando un desarrollo normal de estos. Objetivo: Determinar la relación entre Bruxismo del sueño y los Trastornos Respiratorio del Sueño (TRS) en preescolares. Método: Se realizo un estudio observacional analítico de casos-controles, en niños entre 3-5 años de instituciones educacionales de la V Región. La muestra se realizó mediante muestreo aleatorio simple, determinando 90 niños casos y 90 controles. El diagnostico de bruxismo se llevó a cabo según criterios de Lavine y Montplaisir, sumado la presencia de desgastes dentarios según criterios Manns y Biotti. Para determinar presencia de TRS, se establece mediante el valor obtenido del Pediatric Sleep Questionnaire. Resultado: El $42 \%$ de los niños con bruxismo presentan TRS comparado con el $12 \%$ de pacientes que presentan TRS en el grupo control, es por esto que la presencia de TRS no se 
comporta de manera independiente del hábito de bruxar (Test Chi-Cuadrado: $x 2=20,159$, $\mathrm{gl}=1$, $\mathrm{P}$-valor $=0$ ), indicando una dependencia entre bruxismo del sueño y presencia de TRS. Los niños que presentan TRS tienen 4,99 veces más posibilidades que aquellos sin TRS de presentar Bruxismo del Sueño (IC del 95\% para OR= [2,39-10,42]). Discusión: El riesgo de bruxismo del sueño aumenta en pacientes con TRS, además de observar una alta prevalencia de TRS en pacientes pediátricos siendo coincidentes con otros estudios en pacientes de más edad. Falta mayor cantidad de investigaciones que puedan relacionar el TRS y bruxismo del sueño en niños preescolares. Conclusión: El TRS es un factor que se debe tomar en cuenta cuando los padres consulten por el rechinamiento en el sueño de su hijo.

\section{RESPITAROTY SLEEP DISORDERS AS A RISK FACTOR FOR SLEEP BRUXISM IN PRESCHOOL CHILDREN.}

Introduction: Nowadays bruxism consultations by parents of preschool children are frequent. The tendency of dentists is to consider it as a physiological act, omitting factors that may be altering normal development of them. Objetive: Determine the relationship between bruxism of sleep and the respiratory sleep disorders (TRS) in preschool children. Method: An observational analytical study of case-control, was done in children aged 3-5 years of educational institutions of the V Region. The sample was performed using simple random sampling, determining 90 children cases and 90 controls. Diagnosis of bruxism was carried out according to criteria of Lavine and Montplaisir, added the presence of dental wear according to Manns and Biotti criteria. To determine presence of TRS, it was referred by the value obtained from the Pediatric Sleep Questionnaire. Result: $42 \%$ of children with bruxism present TRS compared with $12 \%$ of patients presenting TRS in the control group. Therefore, the presence of TRS does not behave independently of the habit of bruxing (Chi-square Test: $\mathrm{x} 2=20,159, \mathrm{DF}=1, \mathrm{p}$-value $=$ 0 ), indicating a dependency between sleep bruxism and presence of TRS. Children with TRS are 4.99 times more likely to present sleep bruxism than those without TRS ( $95 \%$ CI for OR $=$ [2, 39-10, 42]). Discussion: The risk of sleep bruxism in patients with TRS increases, in addition to observing a high prevalence of TRS in pediatric patients being matched with other studies in older patients. Greater amount of research that can connect the TRS and in preschool children sleep bruxism is missing. Conclusion: The TRS is a factor that must be taken into account when parents observe grinding in his son dream. 